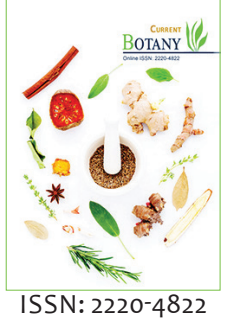

Received: March 09, 2021 Revised: August 19, 2021 Accepted: August 23, 2021 Published: September 20, 202

*Corresponding author: Thajuddin N, E-mail: thajuddin@gmail.com

\section{Development of wound dressing film using methanolic extracts of freshwater microalgae and determining its wound healing ability}

\author{
Soundararajan S', Karkuvel Raja R', Vishnu Chitthan S', Sanjay Prasad S², \\ Thajuddin $\mathbf{N}^{*}$
}

'National Repository for Microalgae and Cyanobacteria - Freshwater (NRMC-F), (Sponsored by DBT, Govt. of India), Department of Microbiology, School of Life Sciences, Bharathidasan University, Tiruchirappalli - 620024, Tamil Nadu, India, ${ }^{2}$ Department of Microbiology, CMS College of Science and Commerce, Coimbatore-641 049, Tamil Nadu, India

\begin{abstract}
Wound healing is a complex process in which bacterial infection is a major cause of delayed wound healing. The occurrence of drug resistance among bacterial pathogens has led to the discovery of new antimicrobial agents from new sources. The present study aimed to identify microalgal metabolites with antibacterial activity and to develop a wound dressing film with their potential healing activity. Microalgal samples were collected from three different freshwater habitats, isolated, making them pure cultures, and the physico-chemical properties of water samples from the respective sampling sites were analyzed. Among the three microalgal isolates, Chlorella sp. NRMC-F-0350 showed antibacterial activity against clinical isolates of E. coli, Klebsiella pneumoniae and Staphylococcus aureus. Additionally, functional groups present in Chlorella sp. NRMC-F-0350 was identified using FTIR analysis. GC-MS analysis identified several antibacterial compounds, viz. benzoxazole, 1,2 Benzene dicarboxylic acid, sistosterol, 9-Octadecanoic acid, eicosane and hexadecane. Wound dressing films were developed and showed evident antibacterial as well as significant wound healing activity (84.5\%). Therefore, the developed films can be used as a potential wound dressing material.
\end{abstract}

KEYWORDS: Freshwater microalgae, wound infection, wound dressing film, wound scratch assay

\section{INTRODUCTION}

A wound can be described as the anatomic destruction of a tissue that may be caused by physical, chemical, thermal, microbial, or immunological damage. Wound healing is the re-establishment of the anatomy and function of an injured tissue for the purpose of restoring approximate prewound characteristics. Based on the repair process, wounds can be of two types: acute or chronic wounds. Acute wounds are tissue injuries that mostly tend to heal entirely, usually within a time period of 8-12 weeks and with the least scarring. Chronic wounds generally tend to reoccur and have a healing time extending beyond 12 weeks (Gonzalez et al., 2016). One of the major factors for wound healing is bacterial colonization and infection. Bacterial infection in wounds can be caused by a broad range of pathogens such as Staphylococcus aureus, Escherichia coli, Klebsiella sp, Streptomyces sp, Propionibacterium sp. and Coryneybacterium sp. (Edwards and Harding, 2004).
Infection in a wound causes a large barrier to healing and can have a bad effect on the patient's quality of life and also the healing rate of the wound. Infected wounds are very painful and hypersensitive. That also results in increased inconvenience for the patient. The most common microorganisms which have known to be associated with wound infection include S. aureus, which was considered in several studies, has been found to account for 20-40\% and P. aeruginosa, which accounts for 5-15\% of the nosocomial infections, with this infection can cause burns and surgery. Many other pathogens such as Enterococci and members of Enterobacteriaceae have been involved, especially in immune compromised patients that lead to abdominal surgery (Stojadinovic et al., 2008).

Wound repair needs a sterile or healthy environment for the body to function normally. That will result in a good healing process with very little scar formation. The important procedure required to keep the process of relieving in progress is to sterilize

Copyright: (C) The authors. This article is open access and licensed under the terms of the Creative Commons Attribution License (http://creativecommons.org/licenses/by/4.0/) which permits unrestricted, use, distribution and reproduction in any medium, or format for any purpose, even commercially provided the work is properly cited. Attribution — You must give appropriate credit, provide a link to the license, and indicate if changes were made. 
the wound from any microbial infection (Mubarak et al., 2013). Repeated usage of different kinds of antimicrobial agents has caused pressure that results in the origination of antibiotic resistant microbial strains, which, in turn, has made research complicated, which causes continued search for new antimicrobial agents. Unfortunately, the decreased rate of new drug discoveries and the very high cost of finding new effective antimicrobial agents make the condition increasingly worrisome. Due to the multiple antibiotic resistance activities of wound pathogens, there is a special need to discover new antibacterial drugs from different natural sources to manage such wound infections (Simes et al., 2018).

Researchers have found that microalgae have a significant attraction as a natural source of bioactive molecules, because they have a high potential to synthesize bioactive compounds in culture, which are very hard to generate through artificial means of chemical synthesis (Thajuddin \& Subramanian., 1994; Parveez et al., 2017). Many of those compounds are accumulated inside the microalgal cells; others are excreted during growth into the environment. The rapid growth and simple nutrient requirements attracted researchers to explore the potential of microalgae species all over the world. To survive against microbial pathogens, they need to develop tolerance/defence mechanisms. These strategies resulted in the synthesis of a high diversity of antimicrobial compounds with different mechanisms of action. Microalgae contribute to the countless chemical or bioactive compounds that they are able to synthesize because of their varied span in an ecosystem. Hence, microalgae are the biggest hope for discovering new types of metabolites. It has been discovered that microalgae have many bioactive compounds which also have guaranteed anticipatory applications, such as antifungal, anticancer, and antibacterial activity (Thangaraj et al., 2020; Dhanasekaran et al., 2020). Therefore, the present work focuses on the development of novel wound dressing films from freshwater microalgae extracts against bacterial pathogens. The developed films were tested for their wound healing ability.

\section{METHODOLOGY}

\section{Physico-chemical, pure culturing and microscopic analysis}

Samples were collected in and around Tiruchirappalli, Tamilnadu in the year 2020 from three sites. Water and microalgae samples were collected from ponds, lakes, and rivers in both plastic vials and polyethylene bags with code numbers concerning the place and area of collection.

\section{Pure Culture and Microscopic Analysis}

The properties of the collected water samples were identified by its evaluation of physico-chemical and biological parameters. The analysis such as $\mathrm{pH}$, alkalinity, total alkalinity, calcium, magnesium, chloride, nitrate, nitrite, total phosphorous, and inorganic phosphorousby using standard methods. The collected microalgal samples were isolated and transferred to tubes and then to conical flasks with BG 11 medium (Rippka et al., 1979). They were maintained under fluorescent lamps (1400lux): 14+10L/D at room temperature and observed under a microscope for topological characterization.

\section{Extraction of Bioactive Metabolites}

The isolated cyanobacterial cultures were cultivated in the medium and the dried biomass was sonicated with liquid nitrogen and then the extraction procedure was carried out with 95\% methanol (Mubarak et al., 2008). The extracts from microalgae were centrifuged at $4000 \mathrm{rpm}$ for $10 \mathrm{~min}$, and then they were further concentrated in a vacuum with reduced pressure. The stock solutions of extract were prepared in DMSO at $50 \mathrm{mg} \mathrm{ml}^{-1}$ for testing the antimicrobial activity.

\section{Antibacterial Analysis}

The antibacterial sensitivity rate of the crude extracts was tested against the bacterial strains viz Escherichia coli, Staphylococcus aureus and Klebsiella pneumoniae by the well diffusion method. agar (Beef extract: 0.2g, Acid digest of casein: $1.75 \mathrm{~g}$, Starch: 1.5g, Agar 1.5g; Total pH: 7.3 0.1for $100 \mathrm{ml}$ ) was prepared and sterilized and poured into plates. Test pathogens of the overnight cultures were grown and $0.1 \%$ of the liquid culture of each test organism was streaked with the help of a cotton swab throughout the Petri plate by rotating the plate at different angles. Wells were cut using a $6 \mathrm{~mm}$ borer on the agar surface of each plate. Crude extracts collected from cyanobacteria were loaded into the wells and the plates were incubated in an incubator at $37 \mathrm{oC}$ for $48 \mathrm{~h}$. The antibacterial activity was determined by measuring the inhibitory zones around the wells on all the plates with test pathogens. The formation of clear zones was observed and measured in millimetres (Dhanasekaran et al., 2005).

\section{FTIR Analysis}

FTIR analysis is used to determine the functional groups present in the microalgae extracts. The scanning was done at a frequency wavelength of 400-4000 cm-1. The scanning result was displayed in transmission analysis.

\section{GC/MS Analysis of Crude Extract}

Methanol extracts were examined by GC/MS at TÜV SÜD South Asia Pvt. Ltd. The GC/MS analysis was performed using a Thermo Scientific, Trace GC Ultra/ISQ Single Quadrupole MS, TG5MS fused silica capillary column $(15 \mathrm{~m}, 0.251 \mathrm{~mm}, 0.1 \mathrm{~mm}$ film thickness). An electron ionization system with an ionization energy of $70 \mathrm{eV}$ was used for GC/MS detection. Helium gas was used as the carrier gas at a constant flow rate of $1 \mathrm{~mL} / \mathrm{min}$. The injector and MS transfer line temperature were set at $280^{\circ} \mathrm{C}$. The identified components were quantified and investigated using a percent relative peak area. A tentative identification was made of the compounds based on the comparison of their relative retention time and mass spectra with those of the NIST, WILLY library data of the GC/MS system. 


\section{Preparation of Wound Dressing Film}

The wound dressing film was developed by the modified method described by Natarajan et al., 2018. Polyvinyl alcohol (2\%) is mixed with distilled water and stirred at room temperature. Under stirring conditions, $2 \%$ of microalgae extracts were added drop wise. $2 \%$ citric acid is added to the solution and stirred for $30 \mathrm{mins}$. The films were poured into a plastic petri dish and kept at $60^{\circ} \mathrm{C}$ for overnight.

\section{Antibacterial Activity of Wound Dressing Film}

The antibacterial activity of the wound dressing film was evaluated against the three test organisms -Escherichia coli, Staphylococcus aureus and Klebsiella pneumoniae. The MullerHinton agar was prepared and sterilized and poured into plates. Test pathogens of the overnight cultures were grown and $0.1 \%$ of liquid culture of each test organism was streaked with the help of a cotton swab throughout the Petri plate by rotating the plate at different angles. Films were cut into $2 \mathrm{cmX} 2 \mathrm{~cm}$ sizes and placed on the plates. The plates were incubated in an incubator at $37 \mathrm{oC}$ for $48 \mathrm{~h}$. Films without extracts were used as a control.

\section{Wound Healing Assay}

The L929 cell lines were seeded into 24-well tissue culture dishes containing coverslips pre-coated with collagen type I $(40 \mathrm{~g} / \mathrm{ml})$ for $2 \mathrm{~h}$ at $37 \mathrm{C}$, at a concentration of $310^{5}$ cells/ml and cultured in a medium containing $10 \%$ FBS to nearly confluent cell monolayers. Then, a linear wound was generated in the monolayer with a sterile 1001 plastic pipette tip. Any cellular debris was removed by washing the coverslips with phosphate buffer saline (PBS). DMEM medium with dimethyl sulfoxide $(0.25 \%)$ (control group), platelet derived growth factor $(2 \mathrm{ng} / \mathrm{ml})$ (as positive control), the commercial Hypericumperforatum oil (1001) and the crude extracts (5 to $100 \mathrm{~g} / \mathrm{l}$ ) were added to coverslips per dose and incubated for $12 \mathrm{~h}$ at $37^{\circ} \mathrm{C}$ with $5 \% \mathrm{CO}_{2}$. The cells were fixed with $4 \%$ paraformaldehyde for $15 \mathrm{~min}$ and stained with 4,6-diamino-2-phenylindole (DAPI) overnight. Three representative images from each coverslip of the scratched areas under each condition were photographed to estimate the relative migration of cells. The data was analysed using CellC software.

\section{RESULTS}

\section{Physico-chemical analysis of water samples}

Total of three water samples were collected and used for the analysis of physic-chemical properties. Physico-chemical analysis of water samples exposed the $\mathrm{pH}$ range from 6.5 to 7.3 , alkalinity from $32 \mathrm{mg} \mathrm{l}^{-1}$ to $116 \mathrm{mg} \mathrm{l}^{-1}$, total alkalinity from $208 \mathrm{mg} \mathrm{l}^{-1}$ to $632 \mathrm{mg} \mathrm{l}^{-1}$, calcium from $528 \mathrm{mg} \mathrm{l}^{-1}$ to $2256 \mathrm{mg} \mathrm{l}^{-1}$, magnesium from $320 \mathrm{mg} \mathrm{l}^{-1}$ to 720 , chloride from $15.99 \mathrm{mg} \mathrm{l}^{-1}$ to $103.99 \mathrm{mg} \mathrm{l}^{-1}$, nitrate from $8.2 \mathrm{mg} \mathrm{l}^{-1}$ to $9.8 \mathrm{mg} \mathrm{l}^{-1}$, nitrite from $2.7 \mathrm{mg} \mathrm{l}^{-1}$ to $5.3 \mathrm{mg}$ $1-1$, total phosphorous from $2.8 \mathrm{mg} 1-1$ to $5.4 \mathrm{mg} \mathrm{l-1}$, inorganic phosphorous from $4.2 \mathrm{mg} \mathrm{l-1}$ to $5.7 \mathrm{mg} \mathrm{l-1}$ (Table 1).

\section{Isolation of Pure Culture and Microscopic Analysis}

Water samples were plated directly on BG 11 media. The colonies showing predominant growth were selected and pure cultures were grown and maintained. About three microalgal species were isolated and observed under light microscopy to determine their shape and morphological characteristics. Figure 1, shows the microscopic images of the isolated Phormidium sp. is found to be dark green pigmented and filamentous in nature. In Figure 2, the pure culture of Oscillatoria sp. is green pigmented and filamentous. Figure 3 shows the pure culture of a single-celled, spherical, green Chlorella sp. NRMC-F-0350

\section{Antibacterial Activity of Extracts}

Antibacterial activity of the methanolic microalgae extracts was determined using well diffusion method. Three pathogens

Table 1: Physico-chemical analysis of water samples

\begin{tabular}{llccc}
\hline S. No & Properties & Area 1 & Area 2 & Area 3 \\
\hline 1 & $\mathrm{pH}$ & 6.7 & 6.5 & 7.3 \\
2 & Alkalinity $\left(\mathrm{mg} \mathrm{l}^{-1}\right)$ & 116 & 76 & 32 \\
3 & Total alkalinity $\left(\mathrm{mg} \mathrm{l}^{-1}\right)$ & 632 & 592 & 208 \\
4 & Calcium $\left(\mathrm{mg} \mathrm{l}^{-1}\right)$ & 2256 & 696 & 528 \\
5 & Magnesium $\left(\mathrm{mg} \mathrm{l}^{-1}\right)$ & 520 & 720 & 320 \\
6 & Chloride $\left(\mathrm{mg} \mathrm{l}^{-1}\right)$ & 103.99 & 43.99 & 15.99 \\
7 & Nitrate $\left(\mathrm{mg} \mathrm{l}^{-1}\right)$ & 9.8 & 8.2 & 9.1 \\
8 & Nitrite $\left(\mathrm{mg} \mathrm{l}^{-1}\right)$ & 4.6 & 5.3 & 2.7 \\
9 & Total phosphorous (mg l-1) & 3.3 & 2.8 & 5.4 \\
10 & Inorganic Phosphorous $\left(\mathrm{mg} \mathrm{l}^{-1}\right)$ & 4.2 & 5.7 & 5.3 \\
\hline
\end{tabular}

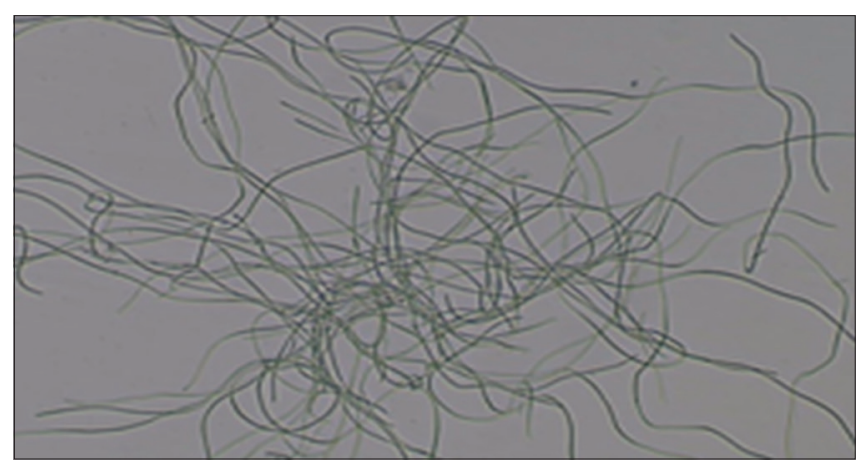

Figure 1: Microscopic analysis of Phormidium sp.

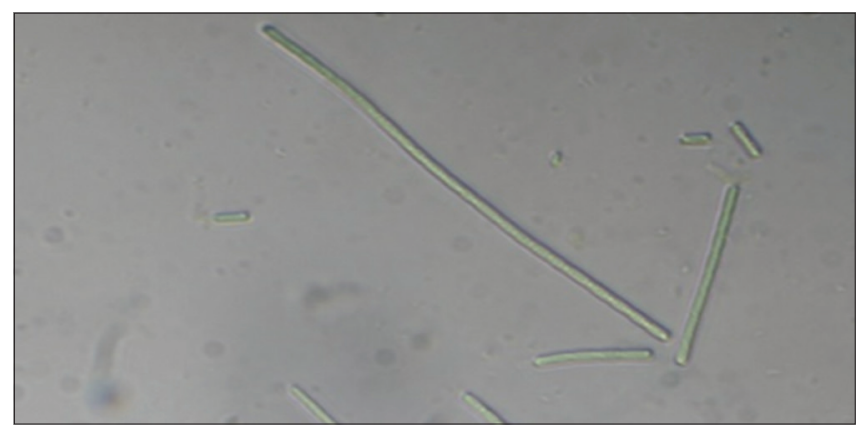

Figure 2: Microscopic analysis of Oscillatoria sp. 
(Escherichia coli, Staphylococcus aureus and Klebsiella pneumoniae) were used to evaluate its antibacterial potential. From the analysis, two microalgal (Phormidium sp. and Oscillatoria sp.) extracts showed no zone of inhibition against all the three test pathogens. Whereas, Chlorella sp. NRMC-F-0350 showed antibacterial activity of $29 \mathrm{~mm}$ against Escherichia coli, $24 \mathrm{~mm}$ against Staphylococcus aureus and $27 \mathrm{~mm}$ against Klebsiella pneumonia. Inhibitory zones were found to be higher for Gram negative pathogen than the Gram positive pathogen (Table-2). Therefore, Chlorella sp. NRMC-F-0350 extracts were used for further analysis and preparation of wound dressing films.

\section{Fourier-transform Infrared Spectroscopy (FTIR) Analysis of Chlorella sp. NRMC-F-0350 Extract}

FTIR analysis is used to determine the functional groups present in the extracts of selected microalgal species. Figure 4 shows the absorption bands observed in the analysis of Chlorella sp. NRMC-F-0350 extract. Absorption bands at $3759 \mathrm{~cm}^{-1}, 3665 \mathrm{~cm}^{-1}$, and $3562 \mathrm{~cm}^{-1}$ denote $\mathrm{OH}$ functional groups. Absorption bands at $2362 \mathrm{~cm}^{-1}, 2313 \mathrm{~cm}^{-1}, 1185 \mathrm{~cm}^{-1}, 1056 \mathrm{~cm}^{-1}, 891 \mathrm{~cm}-1$, and $846 \mathrm{~cm}^{-}$ ${ }^{1}$ correspond to ester (lipid) functional groups. A medium absorption band at $716 \mathrm{~cm}^{-1}$ denotes a benzene derivative

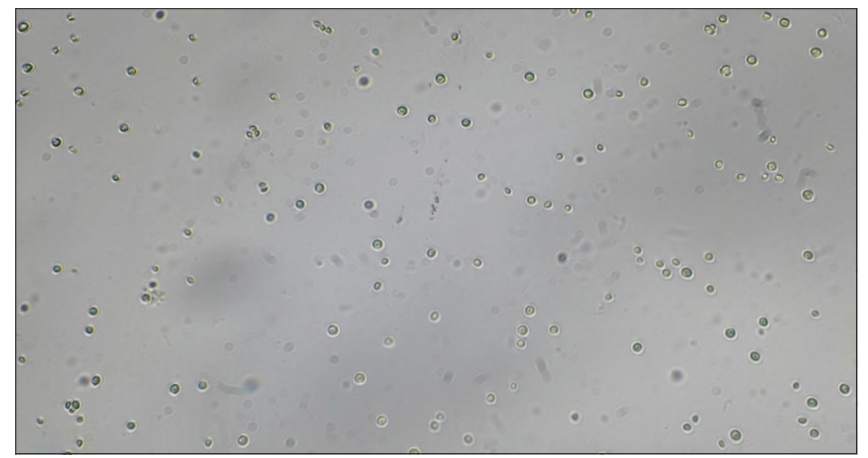

Figure 3: Microscopic analysis of Chlorella sp. NRMC-F-0350 and a strong absorption band at $624 \mathrm{~cm}^{-1}$ corresponds to C-S stretching (Table 3).

\section{GC-MS Analysis of Chlorella sp. NRMC-F-0350 Extracts}

The bioactive compounds present in the Chlorella sp. NRMC-F-0350 extracts were identified by using GC-MS analysis. Figure 5 showed the chromatogram and Table 4 represents the bioactive compounds present in the Chlorella sp. NRMC-F-0350 extract. The major bioactive compounds present in the extracts were found to be Butanoic acid, 3-methyl-, 2-methylbutyl ester,Carbamic acid, methyl-phenyl ester, Benzene, 1,3-bis(1,1-dimethylethyl)-, Hexadecane, Pentanoic acid, 9-Hexadecenoic acid, Eicosane, 9-Octadecanoic acid, Hexanedioic acid, 1-Triacontanol, Gamma sististerol, 1,2 Benzene dicarboxylic acid, Stigmatane and Benzoxazole.

Table 2: Antibacterial activity of microalgae extracts

\begin{tabular}{llccc}
\hline \multirow{2}{*}{ S. No Sample } & \multicolumn{3}{c}{ Inhibitory Zone (mm) } \\
\cline { 2 - 5 } & E. coli & S. aureus & K. pneumoniae \\
\hline 1 & Phormidium sp. & 0 & 0 & 0 \\
2 & Oscillatoria sp. & 0 & 0 & 0 \\
3 & Chlorella sp NRM C-F-0350 & 29 & 24 & 27 \\
4 & Methanol & 0 & 0 & 0 \\
\hline
\end{tabular}

Table 3: FTIR analysis of Chlore/la sp. NRMC-F-0350 extract

\begin{tabular}{lc}
\hline S. No & FTIR peaks $\left(\mathrm{cm}^{-1}\right)$ \\
\hline 1 & 3759.55 \\
2 & 3665.05 \\
3 & 3562.84 \\
4 & 2362.37 \\
5 & 2313.2 \\
6 & 1185.04 \\
7 & 1056.8 \\
8 & 891.916 \\
9 & 846.597 \\
10 & 716.425 \\
11 & 624.823 \\
\hline
\end{tabular}

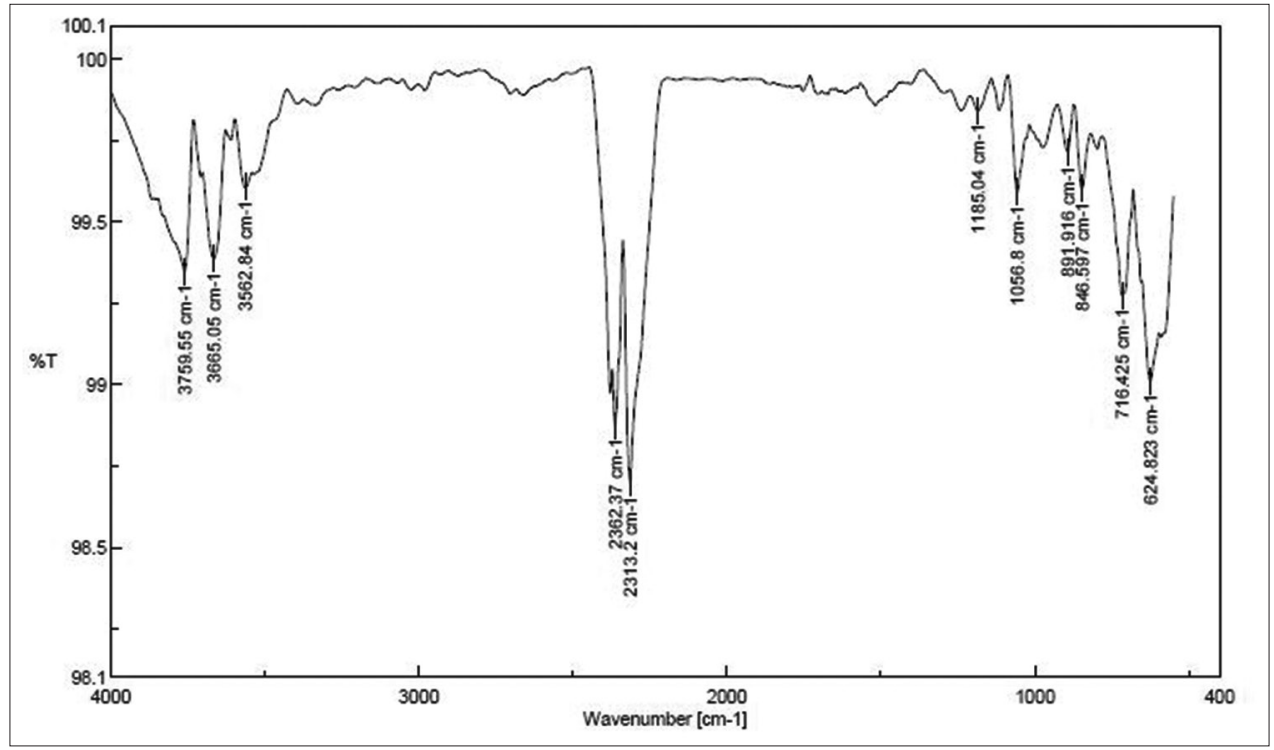

Figure 4: FTIR graph of the algal crude extract 


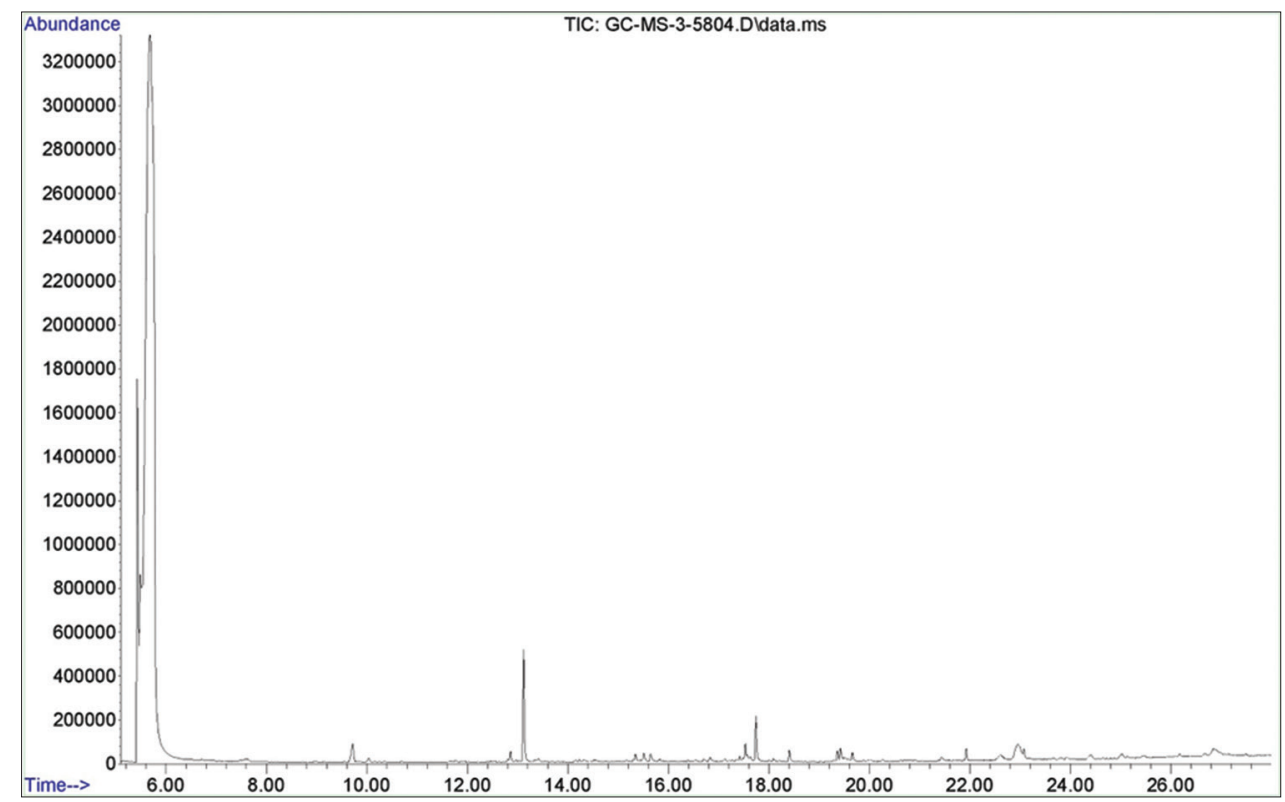

Figure 5: GC-MS Chromatogram of algal crude extract

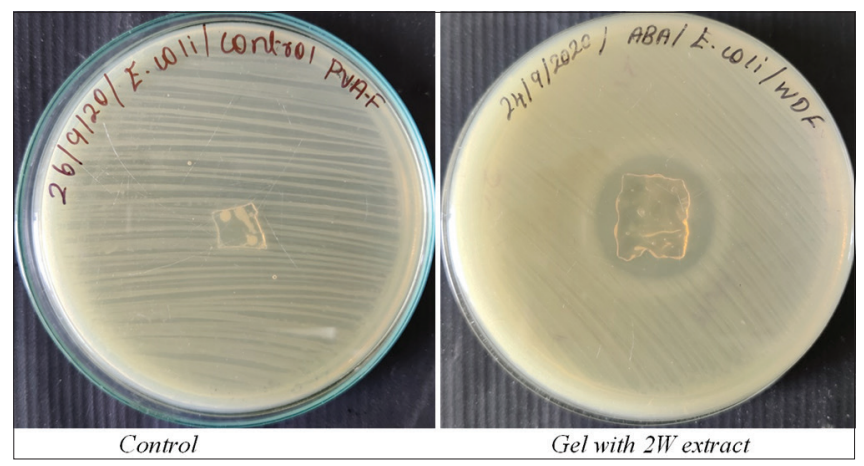

Figure 6: Antibacterial activity of the developed gels against $E$. coli Control Gel with 2W extract

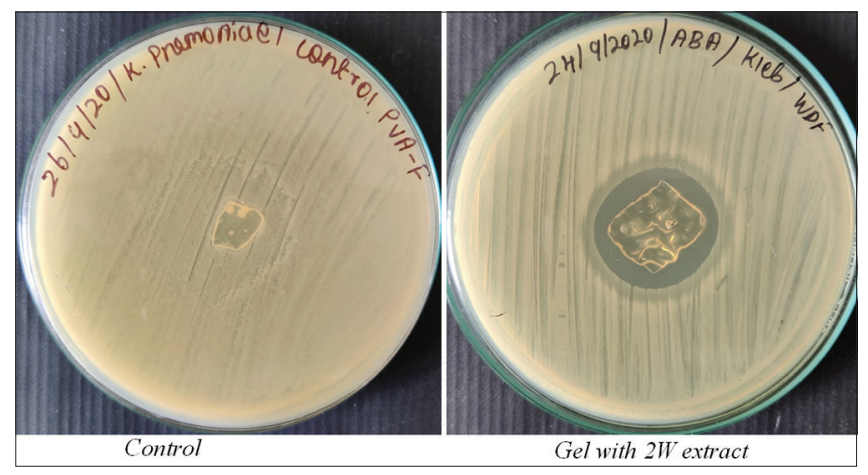

Figure 7: Antibacterial activity of the developed gels against $K$. pneumonia Control Gel with 2W extract

\section{Antibacterial activity of wound dressing film}

Wound dressing films were prepared using microalgal extracts. The developed wound dressing films were subjected to antibacterial analysis. The developed films were compared with plain films with no microalgal extracts. Films prepared

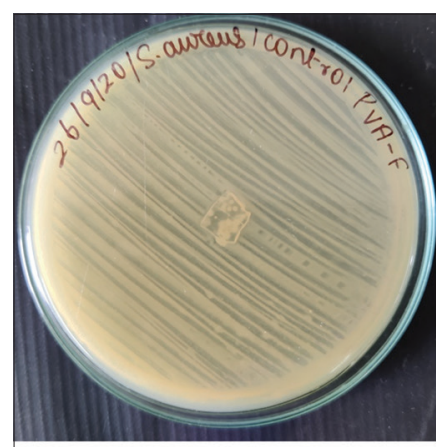

Control

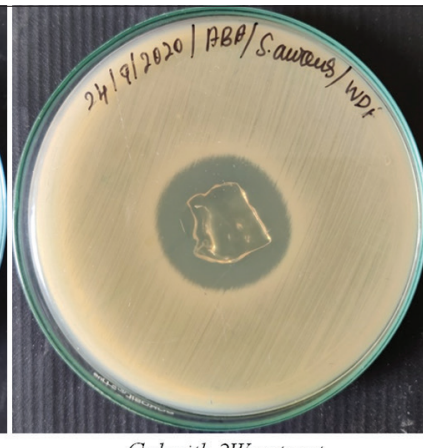

Gel with 2 W extract
Figure 8: Antibacterial activity of the developed gels against $S$. aureus

using microalgal extracts showed significant antibacterial activity against all the test pathogens (E. coli, S. aureus and K. pneumoniae). Figure-6, 7, 8 showed the antibacterial activity of the developed wound dressing films against E. coli, S. aureus and K. pneumonia on comparison with no zones on plain films.

\section{Wound Healing Ability of the Developed Films}

The wound healing ability of the developed films was determined using a wound scratch assay. Four concentrations $(5 \mathrm{~g} / \mathrm{l}, 25 \mathrm{~g} / \mathrm{l}, 50 \mathrm{~g} / \mathrm{l}$ and $100 \mathrm{~g} / \mathrm{l})$ of the films were used to determine the wound healing on L929 cell lines (Figure 9). $5 \mathrm{~g} / \mathrm{l}, 25 \mathrm{~g} / \mathrm{l}, 50 \mathrm{~g} / \mathrm{l}$ films showed significant wound healing at different intervals of time. $50 \mathrm{~g} / \mathrm{l}$ showed maximum healing of $84.5 \%$ compared with $(97.2 \%)$ at $24 \mathrm{~h}$ (Table-5).

\section{DISCUSSIONS}

Wound healing is a complex process which involves several internal and external factors. One of the major reasons for delayed wound healing is bacterial infection. Bacterial infection 


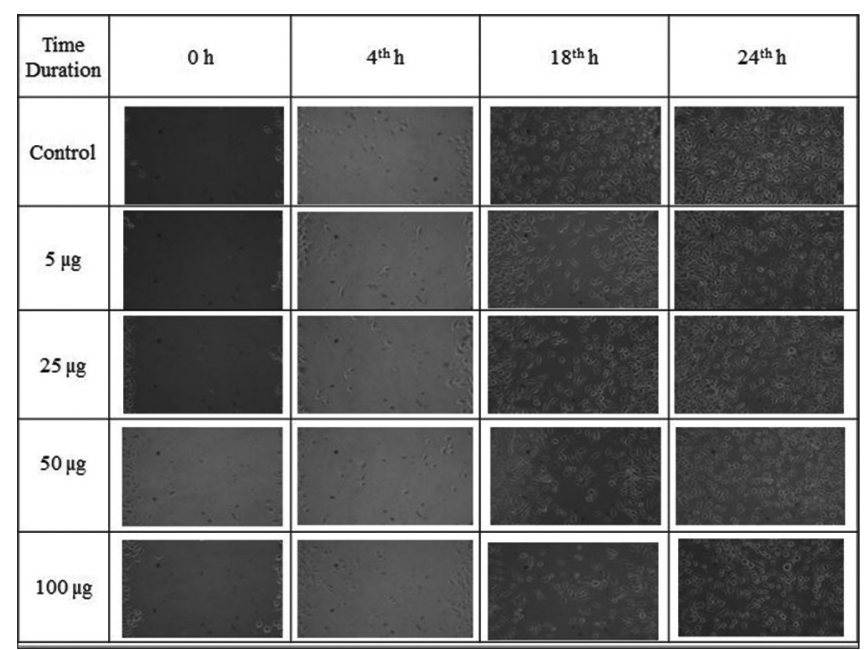

Figure 9: Wound healing ability of developed hydrogel using wound scratch assay

Table 4: GC-MS analysis of Chlorellasp. NRMC-F-0350 extract

\begin{tabular}{llcc}
\hline S. NoBioactive compounds & Retention time Area (\%) \\
\hline 1 & Butanoic acid, 3-methyl-, 2-methylbutyl & 7.609 & 0.27 \\
& ester & & \\
2 & Carbamic acid, methyl-phenyl ester & 5.498 & 1.80 \\
3 & Benzene, 1,3-bis(1,1-dimethylethyl)- & 9.720 & 0.62 \\
4 & Hexadecane & 12.864 & 0.20 \\
5 & Pentanoic acid & 13.119 & 1.98 \\
6 & Eicosane & 15.352 & 0.20 \\
7 & 9-Hexadecenoic acid & 17.541 & 0.54 \\
8 & 9-Octadecanoic acid & 19.429 & 0.20 \\
9 & Hexanedioic acid & 18.407 & 0.25 \\
10 & 1-Triacontanol & 22.618 & 0.43 \\
11 & Gamma sististerol & 22.951 & 1.16 \\
12 & 1,2 Benzene dicarboxylic acid & 23.073 & 0.19 \\
13 & Stigmatane & 25.040 & 0.26 \\
14 & Benzoxazole & 26.851 & 0.55 \\
\hline
\end{tabular}

Table 5: Wound healing ability of developed hydrogel using wound scratch assay

\begin{tabular}{|c|c|c|c|c|c|c|}
\hline \multirow[t]{2}{*}{ Sample } & \multirow[t]{2}{*}{ Conc. $(\mu \mathrm{g} / \mu \mathrm{l})$} & \multirow[t]{2}{*}{ Wound area $(\mu \mathrm{m})$} & \multicolumn{4}{|c|}{$\begin{array}{c}\text { Time intervals }(\mathrm{h}) \\
\text { and percentage of } \\
\text { healing }(\%)\end{array}$} \\
\hline & & & 0 & 4 & 16 & 24 \\
\hline Chlorella sp. & 5 & 4041 & 0 & 5 & 67 & 82 \\
\hline \multirow[t]{3}{*}{ NRMC-F-0350 } & 25 & 4025 & & 3.1 & 70 & 86 \\
\hline & 50 & 4059 & & 2.4 & 73 & 84.5 \\
\hline & 100 & 4049 & & 4.9 & 73 & 82.1 \\
\hline Control & 100 & 4097 & & 11.4 & 83 & 97.2 \\
\hline
\end{tabular}

worsens the condition and results in additional negative effects. Diabetic wounds are highly riskier due to the higher glucose levels. Improper treatment of diabetic foot ulcers may result in amputation (Falanga, 2005). In earlier days, topical applications of antibiotics were given to reduce bacterial colonization. The emergence of drug resistant bacteria has increased the alarming necessity for the development of new antimicrobial agents from new sources (Gopinath et al., 2015; Ganesh et al., 2009). Microalgae can be a potential resource as almost 18,500 new compounds have been identified till now. Several freshwater microalgae species at different geographical locations remain unexplored (Kumar et al., 2010; Balaperiasamy et al., 2014). In the present study, novel antibacterial agents from microalgae species were collected from ponds and lakes in Tiruchirappalli, Tamilnadu.

Three microalgae species were isolated and observed under microscope. The topology and structural characteristics were observed and a cyanobacteria species was identified. Antibacterial activity of the algal extracts was determined against common bacterial pathogens. Chlorella sp. NRMC-F-0350 showed potent antibacterial activity where the other two extracts had no activity. Antibacterial potential of Chlorella sp. NRMC-F-0350 was observed for Gram positive and Gram-negative pathogens. The order of antibacterial potential against the three test pathogens were E. coli, K. pneumoniae, S. aureus. Pratt et al., (1944) isolated the first antibacterial compound from a microalga, Chlorella; a mixture of fatty acids, viz. chlorellin, was found to be responsible for that inhibitory activity against Gram + ve and Gram -ve bacteria. Similarly other microalgae species like Phaeodactylum tricornutum (Desbois et al., 2009), Haematococcus pluvialis (Santoyo et al., 2009), Skeletonema costatum (Naviner et al.,1999), Euglena viridis (Das et al., 2005), S. costatum, Staurastrum gracile, Pleurastrum terrestre, Dictyosphaerium pulchellum, Klebsormidium crenulatum, Chlorococcum sp. (Bhadury and Wright, 2004) Chlamydomonas reinhardtii, Chlorella vulgaris exert antibacterial activity against various pathogens including drug resistant bacteria (Ghasemi et al., 2007).

Similarly, antibacterial activity of the various Chlorella strains isolated from the paddy field was evaluated by Ghasemi et al., 2007. Among the eight isolated strains, Chlorella vulgaris 025 showed significant antibacterial activity of $12 \mathrm{~mm}$ against $S$. aureus and $8 \mathrm{~mm}$ against $\mathrm{S}$. epidermidis. Another study carried out by Hussein et al., 2018 investigated the antibacterial activity of the Chlorella vulgaris isolated from polluted water. Methanolic extracts showed $15 \mathrm{~mm}$ against E. coli and $20 \mathrm{~mm}$ against $S$. aureus. No inhibitory zones were observed for K. pneumonia. Whereas in the present study, methanolic extracts showed higher bacterial inhibition of $27 \mathrm{~mm}$ against E. coli, $24 \mathrm{~mm}$ against $S$. aureus and $29 \mathrm{~mm}$ against $K$. pneumonia. Therefore, the isolated Chlorella sp can be used for the development of novel antibacterial drugs.

From FTIR analysis, the majority of the functional group were related to lipids and alcohol. GC-MS was performed to identify the bioactive compounds responsible for antibacterial activity. Some of the notable compounds with antibacterial mechanisms are found to be benzoxazole (Mishra et al., 2019), 1,2 Benzene dicarboxylic acid (Vijayakumar et al., 2018), sistosterol (Subramaniam et al. 2014), 9-Octadecanoic acid (Rahman et al., 2014), eicosane (Ahsan et al., 2017) and hexadecane (Naeim et al., 2020). The antimicrobial activity of microalgae has been attributed to compounds belonging to several chemical classes - including indoles, terpenes, acetogenins, phenols, fatty acids and volatile halogenated hydrocarbons (Cardozo et al., 2007); for instance, the antimicrobial activity of supercritical 
extracts obtained from the microalga Chaetoceros muelleri were related to its lipid composition (León et al., 2007).

However, the antimicrobial activity detected in several pressurized extracts from Dunaliella salina may be explained not only by several fatty acids, but also by such compounds as a- and b-ionone, b-cyclocitral, neophytadiene and phytol (Herrero et al., 2006).

Biodegradable wound dressing films were prepared using microalgae extracts and these films showed evident antibacterial activity against all test pathogens. Further wound scratch assays are carried out to determine the wound healing ability of developed films. Compared to control of $100 \mathrm{~g} / \mathrm{l}$ showing $97.2 \%$ of healing, films at $50 \mathrm{~g} / \mathrm{l}$ showed $84.5 \%$. Thus, the developed films with good wound healing activity can be used as wound dressing films against bacterial pathogens. This could also be used against drug-resistant pathogens. Detailed characterization of Chlorella sp. NRMC-F-0350 on intensive biochemical, pharmacological, and molecular studies is required for the confirmation and utilization of novel antibacterial compounds in health care aspects.

\section{CONCLUSION}

Three water samples were collected and its physic-chemical properties were determined. Microalgae species present in the water samples were isolated and pure cultures were observed under a microscope. Methanolic extracts of the microalgal extracts were used to determine antibacterial activity. The order of antibacterial activity of Chlorella sp. NRMC-F-0350 of against the three test pathogens such as E. coli, K. pneumoniae, $S$. aureus. Functional groups and bioactive compounds from Chlorella sp. NRMC-F-0350 extracts were evaluated using FTIR and GC-MS analysis. Wound dressing films were prepared and showed evident antibacterial activity. Developed films also showed significant wound healing activity. Therefore, the developed films can be used as a potential antibacterial dressing for enduring wound healing activity.

\section{ACKNOWLEDGEMENT}

Authors gratefully acknowledge University Science Instrumentation Center (RUSA) DST-PURSE Phase II and NRMC-F Sponsored by DBT, Govt. of India.

\section{REFERENCES:}

Ahsan, T., Chen, J., Zhao, X., Irfan, M., \& Wu, Y. (2017). Extraction and identification of bioactive compounds (eicosane and dibutyl phthalate) produced by Streptomyces strain KX852460 for the biological control of Rhizoctonia solani AG-3 strain KX852461 to control target spot disease in tobacco leaf. AMB Express, 7(54), 1-9. https://doi.org/10.1186/s13568-017-0351-z

Al-Harbi, N. A., Shyam Kumar, R., Muthukumar, C., \& Thajuddin, N. (2012). Antibacterial activity of Mentha piperita against selected food spoiling bacteria. African Journal of Biotechnology, 11(90), 15690-15694. https://doi.org/10.5897/AJB12.083

Ananthi, N., Bala krishnan, U., Sudha, S., Babu, M., Velmathi, S., Mubarak Ali, D., \& Thajuddin, N. (2010). A Study on synthesis, characterization, and electrochemical and antibacterial properties of cobalt (ii) complexes of salen-derived ligand. The IUP Journal of Chemistry 3(3), 28-41.

Balaperiasamy, B., Parveez Ahamed, A., Thajuddin, N., \& Panneerselvam, A. (2014). Evaluation of Hypericum wightianum Wall.ex Wight and Arn.extracts for antibacterial activity against human pathogens. International Journal of Current Research, 6(9), 8669-8672.

Bhadury, P., \& Wright, P. C. (2004). Exploitation of marine algae: Biogenic compounds for potential antifouling applications, Planta, 219, 561578. https://doi.org/10.1007/s00425-004-1307-5

Cardozo, K. H. M., Guaratini, T., Barros, M. P., Falcão, V. R., Tonon, A. P., Lopes, N. P., Campos, S., Torres, M. A., Souza, A. O., Colepicolo, P., \& Pinto, E. (2007). Metabolites from algae with economical impact, Comparative Biochemistry and Physiology - C Toxicology and Pharmacology, 146(1-2), 60-78. http://doi.org/10.1016/j. cbpc. 2006.05 .007

Desbois, A. P., Mearns-Spragg, A. \& Smith, V. J. (2009). A fatty acid from the diatom Phaeodactylum tricornutum is antibacterial against diverse bacteria including multi-resistant Staphylococcus aureus (MRSA), Marine Biotechnology, 11, 45-52. http://doi.org/10.1007/ s10126-008-9118-5

Dhanasekaran, D., Thajuddin, N., Panneerselvam, A., \& Chandraleka, S. (2014). Isolation, characterization of antibacterial methyl substituted $\beta$-Lactum compound from Streptomyces noursei DPTD21 in Salt pan Soil, India. Journal of Biologically Active Products from Nature, 4(2), 71-88. https://doi.org/10.1080/22311866.2013.833388

Dhanasekaran, D., Latha, S., Saha, S., Thajuddin, N., \& Panneerselvam, A. (2013). Extracellular biosynthesis, characterisation and in-vitro antibacterial potential of silver nanoparticles using Agaricus bisporus Journal of Experimental Nanoscience, 8(4), 579 - 588. https://doi.or $\mathrm{g} / 10.1080 / 17458080.2011 .577099$

Dhanasekaran, D., Latha, S., Suganya, P., Panneerselvam, A., Kumar, T. S., Alharbi, N. S., Arunachalam, C., Alharbi, S. A., \& Thajuddin, N. (2020). Taxonomic identification and bioactive compounds characterization of Psilocybe cubensis DPT1 to probe its antibacterial and mosquito larvicidal competency. Microbial Pathogenesis, 143, 104138. https:// doi.org/10.1016/j.micpath.2020.104138

Dhanasekaran, D., Panneerselvam, A., \& Thajuddin, N. (2005). Diversity of antibacterial marine streptomyces from coastal region of Cuddalore District, Tamilnadu, India. In: Proceedings of the International Conference on Recent Advances in Marine Antifouling Technology, $420-428$.

Dhanasekaran, D., Rajakumar, G., Sivamani, P., Selvamani, S., Panneerselvam, A., \& Thajuddin, N. (2005). Screening of salt pans Actinomycetes for antibacterial agents. The Internet Journal of Microbiology, 1(2), $1-6$.

Edwards, R. \& Harding, K. G. (2004). Bacteria and wound healing. Current Opinion in Infectious Diseases, 17(2), 91-96. http://doi. org/10.1097/00001432-200404000-00004

Falanga, V. (2005). Wound healing and its impairment in the diabetic foot. Lancet, 366(9498), 1736-1743. http://doi.org/10.1016/S01406736(05)67700-8

Ganesh Manikandan, S., Lakshmi narasimhan, C., Thajuddin, N., \& Saravanan, S. (2009). Antibacterial activity of epicarp extract of Punica granatum L. against Methicillin resistant Staphylococcus aureus (MRSA). Medicinal and Aromatic Plant Science and Biotechnology, $3(1), 52-54$

Ghasemi, Y., Moradian, A., Mohagheghzadeh, A., Shokravi, S., \& Morowvat, M. H. (2007). Antifungal and antibacterial activity of the microalgae collected from paddy fields of Iran: Characterization of antimicrobial activity of Chroococcus dispersus. Journal of Biological Sciences, 7(6), 904-910. http://doi.org/10.3923/jbs.2007.904.910

Ghasemi., Y., Moradian., A., Mohagheghzadeh, A., Shokravi, S., Morowvat, M. H. (2007). Antifungal and Antibacterial Activity of the Microalgae Collected from Paddy Fields of Iran: Characterization of Antimicrobial Activity of Chroococcus dispersus. Journal of Biological Sciences, 7 904-910. https://doi.org/10.3923/jbs.2007.904.910

Gonzalez, A. C. D. O., Costa, T. F., Andrade, Z. A., \& Medrado, A. R. A. P. (2016). Wound healing - A literature review. Anais Brasileiros de Dermatologia, 91(5), 614-620. http://doi.org/10.1590/abd18064841.20164741

Gopinath, P. M., Narchonai, G., Dhanasekaran, D., Ranjani, A., \& Thajuddin, N. (2015). Mycosynthesis, characterization and antibacterial properties of AgNPs against multidrug resistant (MDR) bacterial pathogens of female infertility cases. Asian Journal of Pharmaceutical Sciences, 
10, 138-145. https://doi.org/10.1016/j.ajps.2014.08.007

Herrero, M., Ibanez, E., Cifuentes, A., Reglero, G., \& Santoyo, S. (2006). Dunaliella salina microalga pressurized liquid extracts as potential antimicrobials. Journal of Food Protection, 69(10), 2471-2477. http:// doi.org/10.4315/0362-028X-69.10.2471

Hussein, J. Hussein., Sura, S., Naji., Nebras, M., \& Sahi Al-Khafaji.(2018). Antibacterial properties of the Chlorella vulgaris isolated from polluted water. Iraq. Journal of Pharmaceutical Sciences and Research, 10(10), 2457-2460.

Kumar, R. S., Thajuddin, N., \& Venkateswari, C. (2010). Antibacterial activity of cyanolichen and symbiotic cyanobacteria against some selected microorganisms. African Journal of Microbiology Research, 4(13), 1408-1411. https://doi.org/10.5897/AJMR.9000049

León, M., Antonio, J., Torres, C. F., Toré, A., Martín-Álvarez, P. J., Santoyo, S., Arredondo, B. O., Señorans, F. J., Cifuentes, A., \& Ibáñez, E. (2007). Use of supercritical $\mathrm{CO}_{2}$ to obtain extracts with antimicrobial activity from Chaetoceros muelleri microalga. A correlation with their lipidic content. European Food Research and Technology, 224(4), 505-510. http://doi.org/10.1007/s00217-006-0353-6

Mishra, V. R., Ghanavatkar, C. W., Mali, S. N., Qureshi, S. I., Chaudhari, H. K., \& Sekar, N. (2019). Design, synthesis, antimicrobial activity and computational studies of novel azo linked substituted benzimidazole, benzoxazole and benzothiazole derivatives. Computational Biology and Chemistry, 78, 330-337. https://doi.org/10.1016/j. compbiolchem.2019.01.003

Mubarak Ali, D., Vinodh Kumar, T., \& Thajuddin, N. (2008). Screening of some selected hypersaline cyanobacterial isolates for biochemical and antibacterial activity. Indian Hydrobiology, 11(2), 241-246.

Mubarak Ali., Arun Kumar, D., Rahuman Sheriff, J., Pandiaraj, M., D Sheik Syed Ishack, K.A. \& Thajuddin, N. (2013). Fabrication of Silver Nanoparticles with Cotton for Antibacterial Wound Dressing. Pharmaceutical Nanotechnology, 1(1), 78-82.

MubarakAli, D., Thajuddin, N., Jeganathan, K., \& Gunasekaran, M. (2011). Plant extract mediated synthesis of silver and gold nanoparticles and its antibacterial activity against clinically isolated pathogens. Colloids and Surfaces. B, Biointerfaces, 85(2), 360-365. https://doi. org/10.1016/j.colsurfb.2011.03.009

Naeim, H., Hawiet, A. E., Rahman, R. A. A., Hussein, A., Demellawy, M. A. E., et al. (2020). Antibacterial activity of Centaurea pumilio L. Root and aerial part extracts against some multidrug resistant bacteria. BMC Complementary Medicine and Therapies, 20, 79. http://doi. org/10.1186/s12906-020-2876-y

Naviner, M., Berge, P. B., Durand, B., \& Bris, L. (1999). Antibacterial activity of the marine diatom Skeletonema costatum against aquacultural pathogens. Aquaculture, 174(1-2), 15-24. https://doi.org/10.1016/ S0044-8486(98)00513-4

Parveez Ahamed, A. A., Rasheed, M. U., Noorani, K. P. M., Reehana, N., Santhosh kumar, S., Imran, M.Y.M., Naiyf, A.S., Arunachalam, C., SulaimanAli, A., Akbarsha, M.A. \& Thajuddin, N. (2017). In vitro antibacterial activity of MGDG-Palmitoyl from Oscillatoria acuminata NTAPC05 against extended spectrum beta lactamase producers.
The Journal of Antibiotics, 70(6), 754 - 762. https://doi.org/10.1038/ ja.2017.40

Pratt, R., Daniels, T. C., Eiler, J. J., Gunnison, J. B., Kumler, W. D., Oneto, J. F., Strait, L. A., Spoehr, H. A., Hardin, G. J., Milner, H. W. Smith, J. H., \& Strain, H. H. (1944). Chlorellin, an antibacteria substance from Chlorella. Science, 99(2574), 351-352. https://doi. org/10.1126/science.99.2574.351

Rahman, M. M., Ahmad, S. H., Mohamed, M. T. M., \& Rahman, M. Z. (2014). Antimicrobial Compounds from Leaf Extracts of Jatropha curcas, Psidium guajava, and Andrographis paniculata. Scientific World Journal, 2014, 635240. https://doi.org/10.1155/2014/635240

Santoyo, S., Rodríguez-Meizoso, I., Cifuentes, A., Jaime, L., Reina, G. G-B., Señorans, F.J., \& Ibáñez, E. (2009). Green processes based on the extraction with pressurized fluids to obtain potent antimicrobials from Haematococcus pluvialis microalgae. LWT - Food Science and Technology, 42(7), 1213-1218. https://doi.org/10.1016/j. Iwt.2009.01.012

Simões, D., Miguel, S. P., Ribeiro, M. P., Coutinho, P., Mendonça, A. G., \& Correia, I. J. (2018). Recent advances on antimicrobial wound dressing: A review. European Journal of Pharmaceutics and Biopharmaceutic, 127, 130-141. https://doi.org/10.1016/j.ejpb.2018.02.022

Stojadinovic, A., Carlson, J. W., Schultz, G. S., Davis, T. A., \& Elster, E. A. (2008). Topical advances in wound care. Gynecologic Oncology, 111(2), S70-S80. https://doi.org/10.1016/j.ygyno.2008.07.042

Subramaniam, S., Keerthiraja, M., \& Sivasubramanian, A. (2014). Synergistic antibacterial action of $\beta$-sitosterol-D-glucopyranoside isolated from Desmostachya bipinnata leaves with antibiotics against common human pathogens. Brazilian Journal of Pharmacognosy, 24(1), 44-50. https://doi.org/10.1590/0102-695X20142413348

Terekhova, V. E., Aizdaicher, N, A., Buzoleva, L. S., \& Somov, G. P. (2009). Influence of extra metabolites of marine microalgae on the reproduction of the bacterium Listeria monocytogenes, Russian Journal of Marine Biology, 35, 355-358. https://doi.org/10.1134/ S1063074009040129

Thajuddin, N., \& Subramanian, G. (1994). Marine cyanobacterial flora of south India. In T. A. Sharma, S. S. Saini, M. L. Trivedi \& M. Sharma (Eds.), Current Researches in Plant Sciences. Dehra Dun, Bisen Singh \&Mahendra Pal Singh.

Thangaraj, R., Mubarak Ali, D., \& Thajuddin, N. (2020). Antibacterial activity of biogenic silver nanoparticles synthesized using Phycobiliproteins of Anabaena iyengarii. Research Journal of Biotechnolog, 15(1), $133-139$.

Thennarsu, V., \& Thajuddin, N. (2011). In vitro antibacterial screening of Fungi isolated from marine soils of Andaman Islands. Journal of Basic \& Applied Biology, 5(4), $21-26$.

Vijayakumar, S., Yabesh, J. E. M., Arulmozhi, P., \& Praseetha, P. K. (2018). Identification and isolation of antimicrobial compounds from the flower extract of Hibiscus rosa-sinensis L: In silico and in vitro approaches. Microbial Pathogenesis, 123, 527-535. https://doi. org/10.1016/j.micpath.2018.08.003 